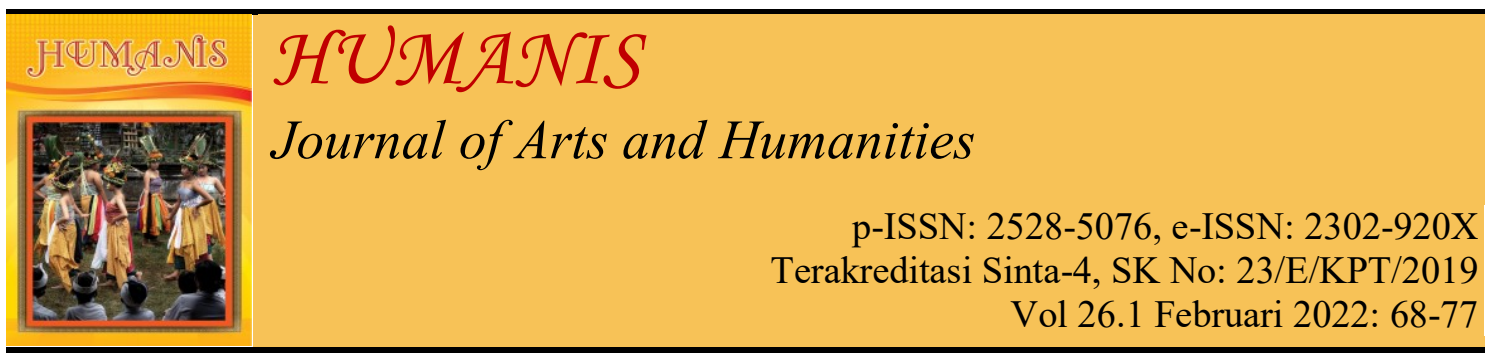

\title{
Produktivitas Sufiks -te dan -shu dalam Bahasa Jepang
}

\author{
Ni Putu Wulan Lestari, Ketut Widya Purnawati, Ni Made Andry Anita Dewi \\ Universitas Udayana, Denpasar, Bali \\ Email korespondensi: wulanlestari231@gmail.com, tuti@unud.ac.id, \\ andry anita@unud.ac.id
}

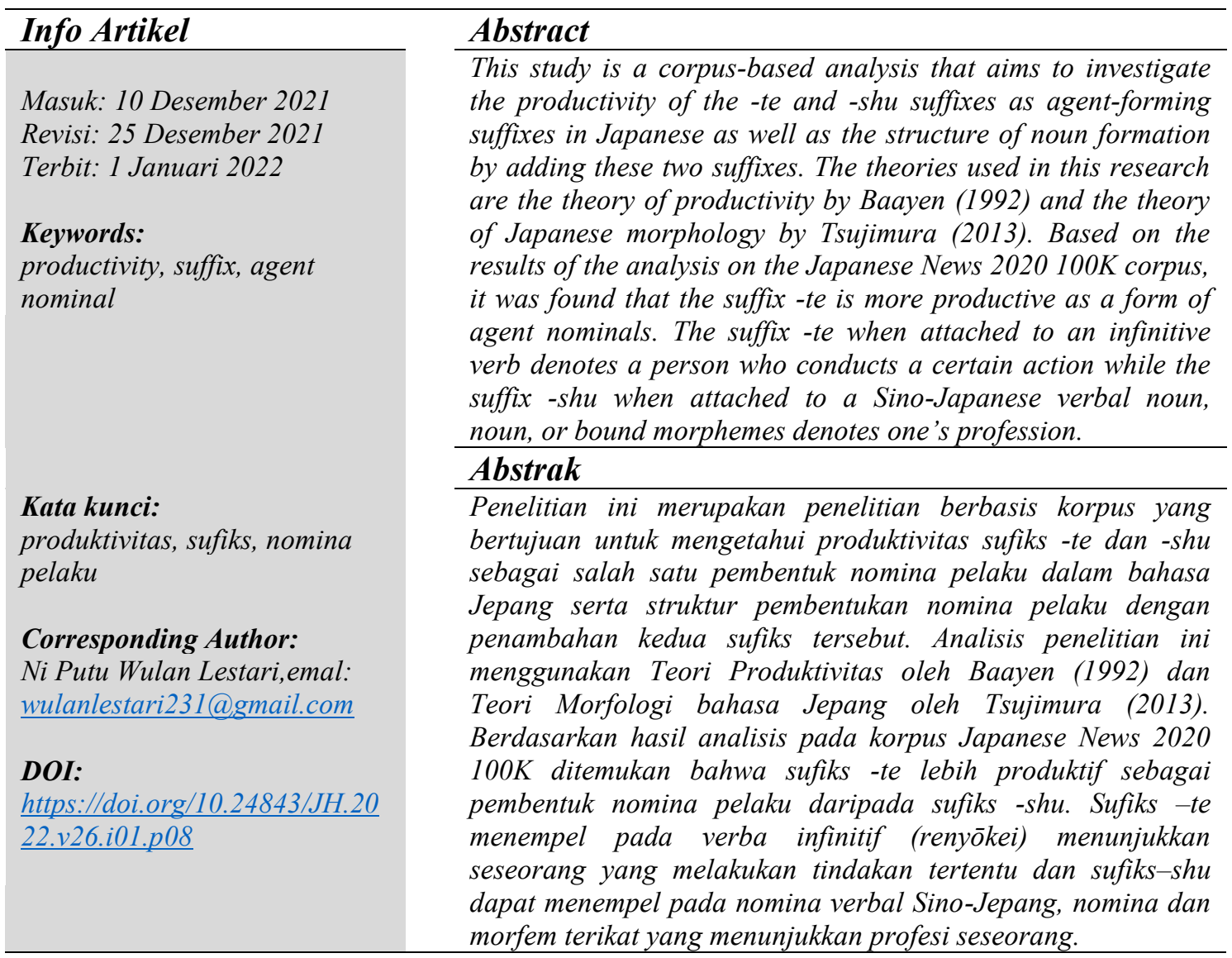

\section{PENDAHULUAN}

Dari sudut pandang tipologi morfologi, bahasa Jepang tergolong sebagai bahasa aglutinatif, banyak elemen predikatif yang muncul setelah verba utama yang berfungsi sebagai morfem terikat (Kishimoto, 2016; Kageyama \& Saito). Artinya bahwa dalam bahasa Jepang, pembentukan kata melibatkan banyak morfem. Morfem adalah satuan terkecil dalam bahasa yang memiliki arti. Morfem dibagi menjadi dua, yaitu morfem bebas dan morfem terikat. Morfem bebas adalah morfem yang dapat berdiri sendiri. Sedangkan morfem terikat adalah morfem yang tidak dapat berdiri sendiri. Morfem terikat dibagi menjadi, prefiks, afiks, dan sufiks atau yang disebut dengan afiks (Booij, 2007, hal. 8-9).

Dalam bahasa Jepang, ada banyak sufiks yang dapat mengubah kelas kata 
suatu kata menjadi kelas kata lain. Menurut Ono (2016, hal. 601) sufiksasi adalah jenis pembentukan kata paling produktif yang menghasilkan nomina pelaku. Ada banyak variasi sufiks yang menunjukkan pelaku dalam bahasa Jepang. Ono (2016, hal. 601-606) juga memberikan deskripsi singkat tentang tujuh sufiks representatif yang sangat produktif, seperti sufiks - sha(者), $k a($ 家 $),-t e$ (手), - shu(手), - $\operatorname{nin}($ 人), nushi( 主), - kyaku( 客) yang jika diletakkan pada akar kata dapat membentuk nomina. Dari tujuh sufiks yang telah disebutkan di atas, penulis memfokuskan penelitian ini pada pembentukan nomina dengan menggunakan sufiks -te(手) dan -

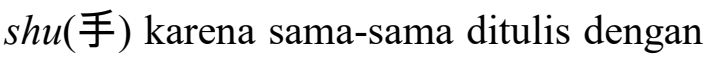
karakter kanji China yang sama, yaitu kanji “手” yang berarti 'tangan'. Di dalam bahasa Jepang, satu buah karakter kanji memiliki dua cara baca yang berbeda, yaitu kun-yomi (cara baca Jepang) dan on-yomi (cara baca Cina) (Kobayashi et al., 2016, hal. 94). Karakter kanji “手” dapat dibaca "te” yang menggunakan cara baca Jepang (kun-yomi) dan "shu" yang merupakan cara baca Cinanya (on-yomi).

Seiring berkembangnya waktu, ilmu linguistik pun semakin berkembang, salah satu perkembangannya adalah penggunaan korpus. Menurut Baker (2010, hal. 93) Corpus Linguistics (selanjutnya disebut Linguistik Korpus) adalah bidang linguistik yang semakin populer, yang (biasanya) menganalisis koleksi teks yang disimpan secara elektronik yang sangat besar, dibantu oleh komputer. Korpus adalah kumpulan data yang mengandung bahasa yang sebenarnya digunakan dalam bentuk elektronik. Korpus adalah sumber informasi yang lebih baik daripada kamus (Booij, 2007, hal. 69). Untuk menggunakan korpus ada beberapa peranti yang bisa digunakan, salah satunya adalah concordancer. McEnery \& Hardie (2012, hal. 35) menjelaskan bahwa concordancer memungkinkan kita untuk mencari data dalam korpus berdasarkan urutan karakter tertentu dengan panjang yang tidak terbatas mungkin berbentuk kata, bagian dari kata, atau frase. Sebuah tabel concordancer menampilkan (pola) suatu kata kunci yang di sebelah kanan dan kirinya dikelilingi oleh kata-kata konteks (Desagulier, 2017, hal. 87).

Sebagian besar peranti yang digunakan dalam korpus juga memungkinkan produksi data frekuensi (production of frequency) dari beberapa deskripsi, misalnya daftar frekuensi kata (a word frequency list), yang mencantumkan semua kata yang muncul dalam korpus dan menentukan setiap kata beberapa kali muncul dalam korpus itu (McEnery \& Hardie, 2012, hal. 2). Korpus memungkinkan kita untuk menganalisis frekuensi tipe, frekuensi token, dan frekuensi hapax yang dapat menunjukkan produktivitas proses morfologis (Rajeg \& Denistia, 2021; Denistia \& Baayen, 2019). Mengacu pada hal tersebut, dapat dikatakan bahwa pendekatan korpus memungkinkan kita untuk melihat jumlah kemunculan nomina yang dibentuk oleh sufiks -te dan $-s h u$ dan kata dasar yang menghasilkan nomina.

Penelitian ini adalah penelitian berbasis korpus yang menganalisis frekuensi tipe, frekuensi token, frekuensi hapax yang dapat menunjukkan produktivitas sufiks -te, dan -shu, serta struktur pembentukan nomina dengan penambahan sufiks-sufiks tersebut.

\section{METODE DAN TEORI}

Penelitian ini menggunakan metode gabungan (kualitatif dan kuantitatif) atau 
yang dikenal dengan mixed method (Creswell dan Creswell, 2018). Creswell dan Creswell (2018, hal. 51) menjelaskan bahwa mixed method melibatkan penggabungan atau integrasi rancangan penelitian kualitatif dan penelitian kuantitatif serta data kualitatif dan kuantitatif.

Data korpus bahasa Jepang yang digunakan dalam penelitian ini adalah korpus berita bahasa Jepang berdasarkan materi di tahun 2020, Japanese News 2020 100K. Korpus ini diambil dari Corpora Collection Leipzig University (Goldhahn, et al., 2012) diakses dan dapat diunduh secara gratis melalui laman https://corpora.unileipzig.de/en?corpusId=jpn news 2020.

Penelitian ini menggunakan piranti AntConc (Anthony, 2020; untuk tutorial AntConc berbahasa Indonesia, lihat Rajeg 2020) yang digunakan untuk mencari kata yang mencerminkan penambahan sufiks -te dan -shu. Untuk mencari data digunakan kombinasi pola pencarian atau disebut juga dengan istilah regular expressions (RegEx) (Desagulier, 2017, hal. 73-74). RegEx yang digunakan adalah

a) ([一-銊])([あ-ん]+手) untuk sufiks -te.

RegEx ini berarti : Carilah kata-kata yang (i) diawali oleh kanji, (ii) yang diikuti oleh karakter hiragana, (iii) dan diikuti oleh sufiks $-t e$.

b) ([一 - 銊 ]+手) untuk sufiks -shu, RegEx ini berarti : Carilah kata-kata yang (i) diawali oleh kanji, (ii) dan diikuti oleh sufiks - shu.

Data yang telah terkumpul selanjutnya diolah dengan Microsoft Office Excel untuk menghitung jumlah kemunculan kata (frekuensi token) dari data. Selain itu, Microsoft Office Excel juga digunakan untuk membuat tabel yang menampilkan frekuensi tipe, token dan hapax sufiks -te, dan -shu yang muncul dalam korpus berita bahasa Jepang di tahun 2020. Serta untuk membuat tabel klasifikasi nomina berdasarkan struktur pembentukannya.

Data yang telah diurut berdasarkan frekuensinya, kemudian dianalisis struktur pembentukkannya dengan bantuan paket $R M e C a b$ (Ishida, 2020) yang merupakan interface dari Mecab (Kudo, 2013) yang dijalankan melalui $R$ (R Core Team, 2020) untuk memecahkan kata dasar dari nomina sekaligus menandai kelas katanya dan memberikan cara bacanya. $R$ adalah sebuah bahasa pemrograman gratis untuk analisis statistik dan grafik (periksa pranala berikut: $\quad$ https://www.r-project.org/). Penelitian ini menggunakan $R$ versi 4.0.3 (2020-10-12) untuk Microsoft Windows.

Data yang telah terkumpul dianalisis secara kuantitatif untuk memperoleh frekuensi token, tipe dan hapaxes sufiks te dan -shu yang muncul dalam korpus berita bahasa Jepang di tahun 2020 dengan menggunakan statistik deskriptif (Gries, 2009, hal. 96; Sugiyono, 2013, hal. 134). Penyajian hasil analisis data dalam penelitian ini disajikan secara formal (menggunakan tabel) dan informal (naratif).

Penelitian ini menggunakan teori Produktivitas yang dikemukakan oleh Bayeen (1992) untuk melihat produktivitas sufiks -te, dan -shu sebagai pembentuk nomina pelaku dalam bahasa Jepang. Produktivitas pembentukan kata erat kaitannya dengan hapax dan frekuensi token dan frekuensi tipe. Hapax adalah tipe kata, dengan bentuk morfologis tertentu, yang frekuensi tokennya hanya satu di dalam korpus (Booij, 2007, hal. 70). Selanjutnya, Bauer (2001, hal. 47) memberikan pengertian tentang frekuensi token dan tipe. Frekuensi tipe (disebut juga "frekuensi leksikal") berkaitan dengan jumlah item dalam bahasa yang berisi item atau proses yang dipertimbangkan. Frekuensi token (juga disebut "frekuensi teks") berkaitan dengan berapa kali item tertentu muncul dalam teks tertentu. 
Untuk mengukur tingkat produktivitas suatu afiks, digunakan rumus indeks produktivitas (Baayen, 1992) sebagai berikut.

$\mathrm{P}=n_{1} / \mathrm{N}$

Keterangan :

$\mathrm{P}$ : Produktivitas

$n_{1}$ : jumlah hapax

$\mathrm{N}$ : jumlah seluruh token

Selain teori yang berkaitan dengan korpus, penelitian ini juga menggunakan teori Morfologi oleh Tsujimura (2013) untuk menganalisis struktur pembentukan nomina dalam bahasa Jepang. Tsujimura (2013) mengidentifikasi kelas kata dalam bahasa Jepang ke dalam nomina, verba, adjektiva, adverbia, posposisi (postpositions), partikel, nomina adjektiva, dan nomina verbal.

\section{HASIL DAN PEMBAHASAN}

Penelitian ini membahas mengenai produktivitas sufiks -te dan -shu, sebagai sufiks pembentuk nomina pelaku dalam Bahasa Jepang dan struktur pembentukan nomina penambahan sufiks-sufiks tersebut. Frekuensi token, tipe dan hapax dari sufiks -te dan sufiks -shu dari total 287.100 tipe kata dan 405.990 token kata yang terdapat dalam korpus Japanese News 2020 100K ditampilkan dalam Tabel 1.1. Dalam sumber data ditemukan 38 token-kata, 16 tipe-kata dan 5 hapaxes nomina yang terbentuk dari hasil penambahan sufiks -te (Tabel 1.2). Untuk nomina yang terbentuk dari hasil penambahan sufiks - shu ditemukan 937 token-kata, 13 tipe-kata dan 1 hapax (Tabel 1.3).

Tabel 1.1

Frekuensi Token, Tipe, Hapax Sufiks -te

$$
\text { dan }- \text { shu }
$$

\begin{tabular}{lccc}
\hline Sufiks & $\begin{array}{c}\text { Frekuensi } \\
\text { token }\end{array}$ & $\begin{array}{c}\text { Frekuensi } \\
\text { tipe }\end{array}$ & Hapax \\
\hline$-t e$ & 38 & 16 & 5 \\
-shu & 937 & 13 & 1 \\
\hline
\end{tabular}

Seperti yang tertera pada Tabel 1.1 frekuensi token sufiks -shu lebih tinggi daripada frekuensi token sufiks -te, namun hapaxes dari sufiks te lebih tinggi daripada sufiks -shu. Indeks produktivitas $\mathrm{P}=n_{1} / \mathrm{N}$ yang artinya jumlah hapax dibagi jumlah token (Baayen, 1992). Berdasarkan indeks produktivitas yang dikemukan oleh Baayen, 1992) untuk sufiks -te sebesar 0,13158 (yang diperoleh dengan membagi nilai hapax dengan nilai token suffix -te) dan sufiks -shu sebesar 0,00107. Mengacu pada Indeks Produktivitasnya semakin jauh ke kanan dari 0 maka indeks produktivitasnya semakin rendah (Bauer, 2001, hal. 149). Hal ini menunjukkan bahwa sufiks -te lebih produktif sebagai pembentuk nomina pelaku daripada sufiks $-s h u$.

Tabel 1.2

Nomina yang Terbentuk dari Hasil Penambahan Sufiks -te

\begin{tabular}{clccc}
\hline \multirow{2}{*}{ No } & \multirow{2}{*}{ Nomina } & \multicolumn{3}{c}{ Frekuensi } \\
& Token & Tipe & Hapax \\
\hline 1 & ninaite & 9 & 1 & \\
2 & Ite & 4 & 1 & \\
3 & odorite & 3 & 1 & \\
4 & hatarakite & 3 & 1 & \\
5 & utaite & 2 & 1 & \\
6 & kikite & 2 & 1 & \\
7 & yomite & 2 & 1 & \\
8 & nomite & 2 & 1 & \\
9 & kakite & 2 & 1 & \\
10 & urite & 2 & 1 & \\
11 & tsukurite & 2 & 1 & \\
12 & kakite & 1 & 1 & 1 \\
13 & katarite & 1 & 1 & 1 \\
14 & narite & 1 & 1 & 1 \\
15 & kaite & 1 & 1 & 1 \\
16 & ukete & 1 & 1 & 1 \\
\hline \multicolumn{5}{r}{} \\
\hline
\end{tabular}


Tabel 1.3

Nomina yang Terbentuk dari Hasil Penambahan Sufiks -shu

\begin{tabular}{|c|c|c|c|c|}
\hline \multirow[b]{2}{*}{ No } & \multirow[b]{2}{*}{ Nomina } & \multicolumn{3}{|c|}{ Frekuensi } \\
\hline & & Token & Tipe & $\begin{array}{c}\text { Hapa } \\
\text { x }\end{array}$ \\
\hline 1 & senshu & 705 & 1 & \\
\hline 2 & kashu & 78 & 1 & \\
\hline 3 & toushu & 69 & 1 & \\
\hline 4 & untenshu & 38 & 1 & \\
\hline 5 & hoshu & 13 & 1 & \\
\hline 6 & joshu & 11 & 1 & \\
\hline 7 & naiyashu & 7 & 1 & \\
\hline 8 & gaiyashu & 4 & 1 & \\
\hline 9 & yuugekishu & 4 & 1 & \\
\hline 10 & kishu & 3 & 1 & \\
\hline 11 & niruishu & 2 & 1 & \\
\hline 12 & buyoushu & 2 & 1 & \\
\hline \multirow[t]{2}{*}{13} & shagekishu & 1 & 1 & 1 \\
\hline & & 937 & 13 & 1 \\
\hline
\end{tabular}

Berikut merupakan pemaparan proses pembentukan nomina pelaku dengan penambahan sufiks -te dan $-s h u$, yang ditemukan dalam data korpus Japanese News $2020100 \mathrm{~K}$ sentences. Pada setiap akhir data berisi informasi mengenai nama berkas korpus dan nomor baris kalimat ditemukan yang dipisahkan dengan tanda ":".

\section{Sufiks -te}

Sufiks -te dalam bahasa Jepang merupakan sufiks pembentuk nomina pelaku yang menunjukkan orang yang melakukan tindakan tertentu (Ono, 2016, hal. 603; Sugioka \& Ito, 2016, hal. 363). Contoh sufiks -te menempel pada verba yang berakhiran konsonan dapat dilihat pada contoh kalimat data berikut.

(1) 本書では、本の読み手であるわれ われに対する問題提起こそあれ、 明確な回答は示されていない。

Honsho dewa, hon no yomite dearu wareware ni taisuru mondai teiki koso are, meikakuna kaitō wa shimesareteinai.

Buku POSP TOP buku GEN pembaca adalah kita DAT terhadap masalah menawarkan terhadap pasti jawaban TOP tidak ditunjukkan.

'Buku ini tidak memberikan jawaban yang jelas atas setiap pertanyaan yang diajukan terhadap kita, para pembaca buku tersebut.'

$$
\text { (jpn_news_2020_100K : 66280) }
$$

Pada data (1) ditemukan penggunaan sufiks -te yang membentuk kata yomite. Pembentukan kata tersebut mengikuti proses sebagai berikut :

$$
\begin{aligned}
& \text { 読み }+ \text { 手 } \rightarrow \text { 読み手 } \\
& \text { Yomi }+ \text { te } \rightarrow \text { Yomite } \\
& \text { Baca }+ \text { tangan } \rightarrow \text { Pembaca }
\end{aligned}
$$

Berdasarkan proses pembentukannya, yomite 'pembaca' terbentuk dari akar verba (renyoukei) yom-i dan sufiks -te. Yom merupakan akar verba dengan cara baca kun-yomi yang berarti 'baca' dan sufiks - te juga dibaca dengan cara baca kun-yomi yang menunjukkan orang yang melakukan tindakan yang dinamai oleh kata kerja. Karena akar verba yom berakhiran konsonan, maka $-i$ disisipkan di antara akar kata dan sufiks -te (Tsujimura, 2013, hal. 150-151). Yom setelah dilekati sufiks -te dan membentuk kata turunan yomite, maka maknanya menjadi pembaca (orang yang membaca).

Terdapat pula contoh lain dari sufiks -te menempel pada verba seperti pada data (7) dalam data korpus Japanese News $2020100 \mathrm{~K}$ sentences. Nomina tersebut dapat dilihat pada tabel 1.4 berikut.

Tabel 1.8

Sufiks Pembentuk Nomina Pelaku dalam Bahasa Jepang

\begin{tabular}{llc}
\hline Sufiks & \multicolumn{1}{c}{ Kata Dasar } & $\begin{array}{c}\text { Frekuensi } \\
\text { Tipe }\end{array}$ \\
\hline$-t e$ & Verba & 16 \\
$-s h u$ & Morfem Terikat & 6 \\
& Nomina Verbal & 4 \\
& Sino-Jepang & \\
& Nomina & 3 \\
\hline
\end{tabular}


Tabel 1.4

\begin{tabular}{llll}
\multicolumn{3}{c}{ Sufiks -te Menempel pada Verba } \\
\hline No & Nomina & Romaji & Arti \\
\hline 1 & 担い手 & ninaite & $\begin{array}{l}\text { Penanggun } \\
\text { g jawab }\end{array}$ \\
2 & 踊り手 & odorite & penari \\
3 & 働き手 & hataraki & pekerja \\
4 & -te & \\
5 & 歌い手 & utaite & penyanyi \\
6 & 聞き手 & kikite & pendengar \\
7 & 読み手 & yomite & pembaca \\
8 & 飲み手 & nomite & peminum \\
9 & 書き手 & kakite & penulis \\
10 & 売り手 & urite & penjual \\
11 & 作り手 & tsukurite & pembuat \\
12 & 描き手 & kakite & pelukis \\
13 & 語り手 & katarite & narator \\
14 & 成り手 & narite & menjadi \\
& 買い手 & kaite & pembeli
\end{tabular}

Selain menempel pada verba yang berakhiran konsonan, dalam data korpus juga ditemukan data sufiks - te menempel pada verba berakhiran vokal. Contoh sufiks -te menempel pada verba berakhiran vokal dapat dilihat pada contoh kalimat data berikut.

(2) 情報の受け手の評価能力を向上さ せる。

Jōhō no ukete no hyōka nōryoku wo kōjō saseru.

Informasi GEN penerima GEN penilaian kemampuan AKU meningkatkan (kausatif).

'Meningkatkan kemampuan penilaian penerima informasi'

(jpn_news_2020_100K : 53490)

Pada data (2) ditemukan penggunaan sufiks - te yang membentuk kata ukete. Pembentukan kata tersebut mengikuti proses sebagai berikut :

$\begin{array}{ll}\text { 受け } & + \text { 手 } \rightarrow \text { 受け手 } \\ \text { Uke } & + \text { te } \rightarrow \text { ukete } \\ \text { menerima } & + \text { tangan } \rightarrow \text { Penerima }\end{array}$

Berdasarkan proses pembentukkannya, ukete 'penerima' terbentuk dari akar verba $u k e$ dan sufiks te. Uke merupakan akar verba dengan cara baca kun-yomi yang berarti 'menerima' dan sufiks -te juga dibaca dengan cara baca kun-yomi yang menunjukkan orang yang melakukan tindakan yang dinamai oleh kata kerja. Uke setelah dilekati sufiks -te dan membentuk kata turunan ukete, maka maknanya menjadi penerima (orang yang menerima).

Terdapat pula contoh lain dari sufiks -te menempel pada verba seperti pada data (2) dalam data korpus Japanese News $2020100 \mathrm{~K}$ sentences, yaitu ite (射 手) yang berarti pemanah.

\section{Sufiks - shu}

Sufiks - shu dalam bahasa Jepang merupakan salah satu sufiks pembentuk nomina pelaku yang menunjukkan profesi seseorang (Ono, 2016, hal. 604). Contoh sufiks -shu menempel pada morfem terikat dapat dilihat pada contoh kalimat data berikut.

(3) 選手入場時の検温やベンチ消毒な ど感染症対策を徹底して行う。

Senshu nyūjō toki no kenon ya benchi no shōdoku nado kansen-shō taisaku o tettei-shite okonau.

Pemain masuk waktu GEN pengukuran suhu dan bangku GEN desinfeksi seperti infeksi tindakan AKU teliti melakukan

'Tindakan pencegahan terhadap infeksi dilakukan seperti pengukuran suhu dan desinfeksi bangku saat pemain masuk.'

(jpn_news_2020_100K : 94283)

Pada data (3) ditemukan penggunaan sufiks - shu yang membentuk kata senshu. Pembentukan 
kata tersebut mengikuti proses sebagai berikut :

$$
\begin{array}{lll}
\text { 選 } & + \text { 手 } & \rightarrow \text { 選手 } \\
\text { Sen } & + \text { shu } & \rightarrow \text { sensh } u \\
\text { Pilih } & + \text { tangan } & \rightarrow \text { pemain }
\end{array}
$$

Berdasarkan proses pembentukannya, kata senshu 'pemain' terbentuk dari morfem terikat sen dan sufiks - shu. Morfem terikat sen dibaca dengan cara baca on-yomi yang berarti 'pilih' dan sufiks -shu dibaca dengan cara baca onyomi yang menyatakan orang, khususnya profesi. Morfem Sino-Jepang sen setelah dilekati sufiks -shu dan membentuk kata turunan senshu maka makna katanya menjadi pemain (menunjuk seseorang yang memiliki keahlian dalam permainan tertentu).

Terdapat pula contoh lain dari sufiks -shu menempel pada morfem SinoJepang seperti pada data (3) dalam data korpus Japanese News $2020 \quad 100 \mathrm{~K}$ sentences. Nomina tersebut dapat dilihat pada tabel 1.5 berikut.

Tabel 1.5

Sufiks -shu Menempel pada Morfem Terikat

\begin{tabular}{llll}
\hline No & Nomina & Romaji & Arti \\
\hline 1 & 助手 & joshu & asisten \\
2 & 投手 & toushu & $\begin{array}{l}\text { pelempar } \\
\text { (bola) }\end{array}$ \\
3 & 捕手 & hoshu & $\begin{array}{l}\text { penangkap } \\
\text { (bola) } \\
\text { penyanyi }\end{array}$ \\
4 & 歌手 & $k a s h u$ & $\begin{array}{l}\text { pembawa } \\
\text { bendera }\end{array}$ \\
\hline
\end{tabular}

Selain menempel pada morfem terikat, pada data korpus ditemukan juga sufiks -shu menempel pada nomina verbal. Contoh sufiks $-s h u$ menempel pada nomina verbal dapat dilihat pada contoh kalimat data berikut.

(4) 感染したのは武漢からのツアー客

の運転手ということです。Kansen shita no wa Wuhan kara no tsuā kyaku no untenshu to iu koto desu.

Terinfeksi-LAMP GEN TOP Wuhan POSP GEN tamu tur GEN pengemudi PKomp mengatakan hal Copula.

'Pengemudi yang terinfeksi adalah pengemudi turis dari Wuhan.'

(jpn_news_2020_100K : 53913)

Pada data (4) ditemukan penggunaan sufiks -shu yang membentuk kata senshu. Pembentukan kata tersebut mengikuti proses sebagai berikut :

$\begin{array}{lll}\text { 運転 } & + \text { 手 } & \rightarrow \text { 運転手 } \\ \text { unten } & +s h u \rightarrow \text { untenshu }\end{array}$

mengemudi + tangan $\rightarrow$ pengemudi

Berdasarkan proses pembentukannya, kata untenshu 'pengemudi' terbentuk dari nomina verbal unten dan sufiks -shu. Unten merupakan nomina verbal dibaca dengan cara baca on-yomi yang berarti 'mengemudi' dan sufiks -shu dibaca dengan cara baca on-yomi yang menyatakan orang, khususnya profesi. Nomina verbal Unten dilekati sufiks -shu membentuk kata turunan untenshu yang berarti 'pengemudi'.

Terdapat pula contoh lain dari sufiks -shu menempel pada nomina verbal seperti pada data (10) dalam data korpus Japanese News $2020 \quad 100 \mathrm{~K}$ sentences. Nomina tersebut dapat dilihat pada tabel 1.6 berikut.

Tabel 1.6

Sufiks -shu Menempel pada Nomina Verbal

\begin{tabular}{llll}
\hline No & Nomina & Romaji & Arti \\
\hline 1 & 遊撃手 & $\begin{array}{l}\text { yuugeki } \\
\text {-shu }\end{array}$ & shortstop \\
2 & 舞踊手 & $\begin{array}{l}\text { buyou- } \\
\text { shu }\end{array}$ & penari \\
3 & & $\begin{array}{l}\text { shageki } \\
\text { 射擊手 }\end{array}$ & penembak \\
& & -shu & \\
\hline
\end{tabular}

Selain menempel pada morfem terikat dan nomina verbal, pada data korpus ditemukan bahwa sufiks $-s h u$ 
menempel pada nomina. Contoh sufiks shu menempel pada nomina dapat dilihat pada contoh kalimat data berikut.

（5）川原田内野手は幼稚園の時から北 上リトルで野球を始め、花巻小学 6 年生時に花巻リトルシニアに加 入。

Kawarada naiyashu wa yōchien no toki kara Kitakami ritoru de yakyū o hajime, Hanamaki shōgakkō rokunensei toki ni Hanamaki ritorushinia $n i \quad k a n y u \overline{.}$

Kawarada Infielder TOP Taman Kanak-Kanak GEN waktu POSP Kitakami little POSP baseball AKU mulai Hanamaki sekolah dasar kelas enam waktu DAT Hanamaki little senior DAT anggota.

'Infielder Kawarada mulai bermain baseball di Kitakami Little ketika dia masih di taman kanak-kanak, dan bergabung dengan Hanamaki Little Senior ketika dia duduk di kelas enam Sekolah Dasar Hanamaki'.

(jpn_news_2020_100K:47683)

Pada data (5) ditemukan penggunaan sufiks $-s h u$ yang membentuk kata naiyashu. Pembentukan kata tersebut mengikuti proses sebagai berikut :

$$
\begin{array}{ll}
\text { 内野 }+ \text { 手 } & \rightarrow \text { 内野手 } \\
\text { naiya }+ \text { shu } & \rightarrow \text { naiyashu } \\
\text { infield }+ \text { tangan } & \rightarrow \text { infielder }
\end{array}
$$

Berdasarkan proses pembentukannya, kata naiyashu 'infielder' terbentuk dari nomina naiya dan sufiks -shu. Naiya merupakan nomina dibaca dengan cara baca on-yomi yang berarti 'infield' dan sufiks -shu dibaca dengan cara baca onyomi yang menyatakan orang, khususnya profesi. Naiya setelah dilekati sufiks -shu dan membentuk kata turunan naiyashu maka makna katanya menjadi infeilder (pemain yang bermain di posisi tengah lapangan).

Terdapat pula contoh lain dari sufiks -shu menempel pada nomina seperti pada data (5) dalam data korpus Japanese News $2020100 \mathrm{~K}$ sentences. Nomina tersebut dapat dilihat pada tabel 1.7 berikut.

Tabel 1.7

Sufiks -shu Menempel pada Nomina

\begin{tabular}{llll}
\hline No & Nomina & Romaji & Arti \\
\hline 1 & 外野手 & Gaiyashu & outfielder \\
2 & 二塁手 & Niruishu & $\begin{array}{l}\text { penjaga } \\
\text { base II }\end{array}$ \\
\hline
\end{tabular}

Berdasarkan analisis data (1) sampai (5) dapat diketahui struktur pembentukan kata dan makna dari masing-masing sufiks pembentuk nomina pelaku dalam bahasa Jepang. Untuk lebih jelasnya, Tabel 1.8 menunjukkan rangkuman struktur pembentukan nomina dengan penambahan sufiks -te dan -shu, pada kata dasar dan frekuensi tipe kata yang dihasilkan dengan penambahan sufikssufiks tersebut dalam data korpus Japanese News 2020100 K sentences.

\section{SIMPULAN}

Berdasarkan analisis yang telah dilakukan, dapat ditarik simpulan mengenai produktivitas sufiks pembentuk nomina pelaku dan struktur pembentukan nomina dengan penambahan sufiks -te dan -shu yang ditemukan dalam data korpus Japanese News $2020 \quad 100 \mathrm{~K}$ dijabarkan sebagai berikut.

Berdasarkan jumlah tipe dan hapaxnya dari tiap-tiap sufiks yang ditemukan dalam data korpus menunjukkan bahwa sufiks -te lebih produktif sebagai pembentuk nomina pelaku daripada sufiks -shu. Dengan kata lain sufiks -te memiliki potensi yang lebih tinggi untuk menghasilkan nomina baru dibandingkan dengan sufiks - shu.

Dalam data korpus Japanese News $2020100 \mathrm{~K}$ ditemukan bahwa sufiks -te menempel pada verba infinitif (renyōkei), sedangkan sufiks-shu menempel pada nomina verbal, nomina, dan morfem yang termasuk ke dalam kelompok SinoJepang. Sufiks te berfungsi untuk 
menunjukkan makna seseorang yang melakukan tindakan tertentu, sedangkan sufiks -shu berfungsi untuk membentuk nomina pelaku yang menunjukkan profesi seseorang.

Kategori tipe semantis pelaku ini tidak menjadi fokus utama penelitian ini dan akan dibiarkan menjadi topik penelitian lanjutan.

\section{DAFTAR PUSTAKA}

Anthony, L. (2020). AntConc (Version 3.5.9) [Computer Software]. Tokyo, Japan: Waseda University. Available from https://www.laurenceanthony.net/ software

Baayen, R. H. (1992). Quantitative Aspect of Morphological Productivity. Booij, G. E. and van Marle, J. (eds); Yearbook of Morphology 1991, pp. 109-149. Kluwer Academic Publishers, Dordrecht.

Baker, Paul. (2010). Corpus Methods in Linguistics. In Litosseliti Lia (Ed.), Research Methods in Linguistics. (pp. 93-113). Continnum International Publishing Group.

Bauer, L. (2001). Morphological Productivity (Cambridge Studies in Linguistics). Cambridge: Cambridge University Press.

Booij, G. (2007). The Grammar of Words. Oxford: Oxford University Press.

Creswell, J. W., \& Cresswell, D. (2018). Research design: Qualitative, quantitative, and mixed methods approaches. (5th ed). Los Angeles: SAGE.

Denistia, K. \& Baayen, R. H. (2019). The Indonesian prefixes PE- and PEN-
: A study in productivity and allomorphy. Morphology. https://doi.org/10.1007/s11525$\underline{\text { 019-09340-7 }}$

Desagulier, G. (2017). Corpus Linguistics and Statistics with R: Introduction to Quantitative Methods in Linguistics. New York: Springer.

Goldhahn, D., Eckart, T. \& Quasthoff, U. (2012). Building large monolingual dictionaries at the Leipzig Corpora Collection: From 100 to 200 languages. In Proceedings of the 8th Language Resources and Evaluation Conference (LREC) 2012, 759765. Istanbul. http://www.lrecconf.org/proceedings/lrec2012/pd f/327 Paper.pdf

Gries, S. (2009). Statistics for Linguistics with R: A Practical Introduction. Berlin, New York: De Gruyter Mouton. https://doi.org/10.1515/97831102 $\underline{16042}$

Ishida, M. (2020). RMeCab : parsing Japanese texts with mecab-0.996 / $R-4.0 .3$. R Package version 1.05 . Retrieved from https://github.com/IshidaMotohir $\underline{\mathrm{o} / \mathrm{RMeCab}}$

Kageyama, T. \& Saito, M. (2016). 1. Vocabulary strata and word formation processes. In $\mathrm{T}$. Kageyama \& H. Kishimoto (Ed.), Handbook of Japanese Lexicon and Word Formation (pp. 11-50). Berlin, Boston: De Gruyter Mouton. https://doi.org/10.1515/97816145 12097-005 
Kishimoto, H. (2016). 19. Idioms. In T. Kageyama \& H. Kishimoto (Ed.), Handbook of Japanese Lexicon and Word Formation (pp. 665702). Berlin, Boston: De Gruyter Mouton.

https://doi.org/10.1515/97816145 $\underline{12097-023}$

Kobayashi, H., Yamashita, K. \& Kageyama, T. (2016). 3. SinoJapanese words. In T. Kageyama \& H. Kishimoto (Ed.), Handbook of Japanese Lexicon and Word Formation (pp. 93-132). Berlin, Boston: De Gruyter Mouton. https://doi.org/10.1515/97816145 $\underline{12097-007}$

Kudou, T. (2013). MeCab: Yet Another Part-of-Speech and Morphological Analyzer. Available from https://taku910.github.io/mecab/

Lieber, R. (2009). Introducing Morphology (Cambridge

Introductions to Language and Linguistics). Cambridge University Press. doi:10.1017/CBO9780511808845

McEnery, T., \& Hardie, A. (2012). Corpus Linguistics: Method, Theory and Practice (Cambridge Textbooks in Linguistics). Cambridge University Press. https://doi.org/10.1017/CBO9780 $\underline{511981395}$

Ono, N. (2016). 17. Agent nominals. In T. Kageyama \& H. Kishimoto (Ed.), Handbook of Japanese Lexicon and Word Formation (pp. 559 630). Berlin, Boston: De Gruyter Mouton.

https://doi.org/10.1515/97816145 $\underline{12097-021}$
R Core Team. (2020). R: A Language and Environment for Statistical Computing. Vienna, Austria. Retrieved from https://www.Rproject.org/

RStudio Team. (2020). RStudio: Integrated Development Environment for $R$. Boston, MA. Retrieved from http://www.rstudio.com/

Rajeg, G. P. W. \& Denistia, K. (2021). A study in productivity of Indonesian causative per- and kan. figshare. Presentation. https://doi.org/10.6084/m9.figshar e.14633133.v3

Rajeg, G. P. W. (2020). Tutorial AntConc. [Video]. YouTube. https://www.youtube.com/playlist ?list=PL6kE55FBuZnVj2SOrx75 0991FiPq TmCt

Sugiyono. (2013). Metode Penelitian Kuantitatif, Kualitatif, dan $R \& D$. Bandung: Alfabeta

Sugioka, Y. \& Ito, T. (2016). 10. Derivational affixation in the lexicon and syntax. In $T$. Kageyama \& H. Kishimoto (Ed.), Handbook of Japanese Lexicon and Word Formation (pp. 347386). Berlin, Boston: De Gruyter Mouton.

https://doi.org/10.1515/97816145 12097-014

Tsujimura, N. (2013). An Introduction to Japanese Linguistics (3rd ed.). Malden: Wiley Blackwell.

Yule, G. (2010). The Study of Language (4th ed.). Cambridge: Cambridge University Press. doi:10.1017/CBO9780511757754 